\title{
Independent Living Needs of Young Adults with Intellectual Disabilities ${ }^{12}$
}

\author{
Gizem Yıldız ${ }^{3}$, Atilla Cavkaytar ${ }^{4}$
}

\begin{abstract}
The aim of this study was to determine the independent living needs of young adults with intellectual disability (YAID) in preparing for adulthood and work life. This study was conducted using the phenomenological design, which is one of the qualitative research methods. 10 YAIDs were observed, their skills were evaluated, and semi-structured interviews were conducted with a total of 30 individuals consisting of 10 individuals from each group, with their parents, employers, and teachers regarding the employment education course. The results of the study indicated that YAIDs had difficulties in independent living skills and adaptation to work rather than employment skills while preparing for adulthood and work life and that those difficulties were mostly due to the lack of knowledge and skills. It was revealed that the needs of YAIDs in preparing for work life were primarily personal care and hygiene, interpersonal skills and self-determination, employability skills, sexual education, and safety skills.
\end{abstract}

Keywords: Young adults with intellectual disabilities, independent living, determination of needs.

\footnotetext{
1 This article was produced from Gizem Yıldiz's doctoral thesis entitled "Effectiveness of Pre-Employment Independent Life Education Program Designed for Young Adults with Intellectual Disability". and within the scope of Project number 1609E614 accepted by Anadolu University Scientific Research Projects Commission.

${ }^{2}$ On 10.10.2016 ethical committee approval numbered 105775 was obtained from Anadolu University Ethics Committee.

3 Res.Asst.Dr., Anadolu University, Faculty of Education, Department of Special Education, gizemy@anadolu.edu.tr, https://orcid.org/0000-0003-2693-6264

4 Prof.Dr., Anadolu University, Faculty of Education, Department of Special Education, acavkayt@anadolu.edu.tr, https://orcid.org/0000-0001-8067-1602 


\title{
Zihin Yetersizliği Olan Genç Yetişkinlerin Bağımsız Yaşam Gereksinimleri
}

\begin{abstract}
$\ddot{O} z$
Zihin yetersizliği olan bireyler örgün eğitimlerini tamamladıktan sonra gençlik ve yetişkinlik dönemlerinde okul sonrası eğitimlere katılabilmektedirler. Bu süreçte okuldan mezuniyet ve çalışma yaşamına hazırlanma gibi geçiş dönemleri bireylerin bağımsızlığa adım attığı ve desteğe gereksinim duyduğu dönemlerdir. Bu çalışmanın amacı zihin yetersizliği olan genç yetişkinlerin (ZYOGY) yetişkinliğe ve çalışma yaşamına hazırlanmalarındaki bağımsız yaşam gereksinimlerini belirlemektir. Araştırma, bu amacı gerçekleştirmek üzere nitel araştırma yöntemlerinden fenomenolojik desen ile yürütülmüştür. Çalışmaya amaçlı örneklemeyle 10 ZYOGY, 10 ebeveyn, 10 işveren ve 10 öğretmen olmak üzere toplam 40 kişi katılmıştır. İşveren, öğretmen ve ebeveynlerden oluşan 30 kişiyle yarı yapılandırılmış görüşmeler yapılmış, 10 ZYOGY ise gözlenerek beceri kontrol listesi aracıllı̆̆yla beceri ve davranışları değerlendirilmiştir. Gerçekleştirilen yarı yapılandırılmış görüşmelerden elde edilen veriler tümevarım analiziyle, kontrol listesinden elde edilen veriler betimsel analizle analiz edilmiştir. Araştırma bulguları ZYOGY'lerin yetişkinliğe ve çalışma yaşamına hazırlanmada bağımsız yaşam becerilerinde güçlük yaşadıkları bu nedenle okul sonrasında bir bağımsız yaşam eğitimine gereksinim olduğunu göstermiştir. ZYOGY'lerin bu dönemde yoğunlukla kişisel bakım ve temizlik, kişilerarası beceriler, güvenlik ve sağlık becerileri ve istihdam edilebilirlik becerilerine gereksinim duydukları görülmüştür.
\end{abstract}

Anahtar Sözcükler: Zihin yetersizliği olan genç yetişkinler, bağımsız yaşam, gereksinim belirleme. 


\section{Introduction}

Some individuals are affected by intellectual, physical or psychological differences more than others and can complete their development by needing special arrangements beyond the norms. The group that differs in terms of intellectual developmental characteristics among these individuals is called individuals with intellectual disability (IID). Intellectual disability is a disability characterized by significant limitations in both intellectual functioning and adaptive behavior, which includes several everyday social and practical skills (Schalock et al., 2010).

In Turkey, IIDs can start formal education until the age of 27 and can benefit from special education services (Ministry of National Education, 2018). After the completion of formal education, they can participate in post-secondary education and informal education during youth and adulthood. In this period including the transition to the adulthood period, new stages such as graduation from school, work life, and marriage appear for IIDs. In the transition to the adulthood period, a more independent and individual life begins for IIDs along with the fact that their attachment to their parents decreases and that they grow mature physically, psychologically, cognitively, emotionally, and socially (Belva \& Matson, 2013; Faloon \& Rehfeldt, 2008). This period corresponds to the period after 18 years of age with the end of the school. Arnett (2007) discussed the age between 18 and 25 years as a significant period of development covering the period between adolescence and adulthood. IIDs in this period can be expressed as young adults with intellectual disability (YAID) (Harris, 2006; Sabornie \& deBettencourt, 2009; Wehman, 2013).

It appears that many independent living skills that are necessary throughout life play a significant role in the period of preparation for adulthood (Steere, Rose, \& Cavaiuolo, 2007; Wehman, 2013). In the Life Centered Education (LCE) Program, which was first developed by Brolin and then revised and extended in 2012, it is indicated that individuals with special needs are required to have competence in three main areas in order to live independently. These key areas are (a) daily living skills, (b) self-determination and interpersonal skills, and (3) employment skills (Wandry, Wehmeyer, \& Glor-Scheib, 2013). 
YAIDs may have difficulty in exhibiting these independent life skills (Alwell \& Cobb, 2009). When the studies evaluating YAIDs' independent living needs are examined, it appears that these individuals need support on daily life skills (Hilgenkamp, Wijck, \& Evenhuis, 2011; Lane, 2012; Sunder, 2007), the skills necessary to live in a separate home, personal care and hygiene skills, money management, friendship and neighbor relations (Luthra, Högdin, Westberg, \& Tideman, 2018; Mueller \& Stack-Dunne, 1989; Sunder, 2007; Thoma et al., 2016; Yuan Ru, 2015), domestic skills, self-care skills, community adaptive skills (Belva \& Matson, 2012; Kaya 2017; Mansell, Ashman, McDonald, \& Beadle-Brown, 2002), leisure time activities (Kaya, 2017), shopping, home management, transportation and self-determination (Lane, 2012), travelling skills, employment skills, self-defence, and avoidance of abuse (Sunder, 2007). In the investigations conducting the validity and reliability studies of the Supports Intensity Scales-Adult Version (SIS-A), it was indicated that IIDs above 16 years of age mainly needed lifelong education support and also supports in behavioral problems, the field of health, social and community life, daily life, work life, communicating and stress management (Chou, Lee, Chang, \& Pei-Lung, 2013; Harries, Guscia, Kirby, Nettelbeck, \& Taplin, 2005; Lamoureux-Hebert, Morin, \& Crocker, 2010; Thompson et al., 2009; Wehmeyer et al., 2009).

Folk, Yamamoto and Stodden (2012) emphasized that there were three main transition areas after school that interacted with each other, including independent living, employment, and community \& social engagement and that basic life skills, employability skills, and academic skills should be acquired to succeed in these areas. In another study, it was stated that social skills such as taking responsibility, getting along with people, adapting, and establishing appropriate communication-interaction were more important rather than employment or daily life skills in work life (Agran, Hughes, Thoma, \& Scott, 2016). In the report published by the Council for the Education of Exceptional Children (CEC) (2011), it was emphasized that the fact that individuals with disability had difficulty in participating in the workforce was due to the lack of knowledge and skills related to independent living and that these skills should be studied for sustainable employment.

In other studies, it was indicated that women with ID were less employed and lived independently than men with ID, and social disadvantages of being a woman were emphasized as one of the reasons for it (Hsieh, Rimmer, \& Heller, 2012; Nye-Lengerman, Narby, \& 
Pettingell, 2017). In parallel to them, other studies concluded that women with ID were more vulnerable to physical and sexual abuse compared to men with ID, and therefore, these individuals needed intensive support in self-defense (Gil-Llario, Morell-Mengual, DiazRodriguez, \& Ballester-Arnal, 2018; Gimenez-Garcia, Gil-Llario, Ruiz-Palomino, \& DiazRodrigez, 2017). In the study carried out by Hickson, Khemka, Golden and Chatzistyli (2008), it was reported that women with ID who were abused had more difficulties in participation in work life, decision making, and community participation compared to women with ID who were not abused. Similarly, it was indicated that YAIDs had significant difficulties due to their lack of knowledge and skills in sexuality and self-determination, and they did not manage relationships and needed sexual education in preparing for independent living (Brown \& McCann, 2018; Healy, McGuire, Evans, \& Carley, 2009; Lumley, Miltenberger, Long, Rapp, \& Roberts, 1998; Tice \& Harnek, 2008). As it is seen, YAIDs need support in many different independent living areas, from personal care to social skills, from employment skills to sexual education.

In studies in Turkey, it was indicated that YAIDs experience difficulties on getting into a job, doing the job as it should be, sustained employment, adaptation to work (Cosgun Basar, 2010), and YAIDs need to gain responsibility, quick thinking, technology skills, adaptation, teamwork, communication, academic process, vocational skills, and self-management skills in order to have a job (Baran \& Cavkaytar, 2007; Gunes \& Akcamete, 2014). Also, teachers and counselors said that there were shortcomings in the job preparation training process of students (Ozbek, Girli, \& Ozturk, 2017). The reasons for the low employment rates of YAIDs; it is stated as the lack of experience, knowledge, self-confidence, responsibility, self-management and communication, and difficulties in adapting to work (Gundogdu, 2010; Gursel, Ergenekon, \& Batu, 2007; Hasircioglu, 2006; IPA, 2018; Ozbey, 2015).

In the literature, there are studies that had difficulties were emphasized, and the needs for support in the independent living area were revealed. However, there were limited studies on YAIDs' post-secondary needs, especially independent living needs in work life, were determined by consulting the relevant stakeholders and by directly monitoring YAIDs. The aim of this study was to determine the needs of YAIDs in preparing for adulthood and work life based on the observed performance of YAIDs and the opinions of parents, teachers, and employers. 


\section{Methodology}

This study was conducted using the phenomenological research design, which is one of the qualitative research methods. Semi-structured interviews were conducted with 30 individuals consisting of employers, teachers, and parents, and 10 YAIDs were observed through the Skill Control List.

\section{Participants}

Participants were determined by criterion sampling, which is one of the purposeful sampling types. The criteria for each group of participants were as follows:

- Teachers; being special education teachers covering workshop courses in vocational training and employment education centers,

- Employers; being the authorized person to recruit individuals in the workplace where YAIDs are still employed,

- Parents; having a child with ID over the age of 18 ,

- YAIDs; being an individual over the age of 18 , working or continuing to receive work education, with a diagnosis of intellectual disability, and a graduate from formal education.

In phenomenological studies with purposeful sampling, it is stated that the sample size may be between three and 10 (Creswell, 2014). In this study, 10 individuals were reached for each group determined.

The parents consisted of one male and nine females, the age range was 40-74 years. Among the parents, all mothers were housewives, and the father was a retired worker. The teachers consisted of four males and six females, the age range was $25-48$ years. $50 \%$ of them graduated from mentally disabled teaching, 30\% of them graduated from hearing and visually impaired teaching, $10 \%$ of them graduated from primary school teaching, and $10 \%$ of them graduated from weaving teaching. The employers consisted of two females and eight males, the age range was 25-65 years. The employers were working in the food, service, imports, and electronics sectors, in director position. 
YAIDs consisted of five females and five males, the age range was $21-36$ years. While $50 \%$ of the YAIDs were third-degree graduates, the other $50 \%$ of them were first-degree graduates, and all of them were continuing work education. The whole data collection process was carried out by the first author. The interview data were coded by another independent expert.

\section{Settings}

Semi-structured interviews were conducted in a quiet room suitable for interviews with parents in their homes, with employers in their workplaces, and with teachers in their schools. YAIDs were observed in workshops and workplaces where they continued their work education.

\section{Data Collection and Instruments}

Semi-structured interviews (30 individuals consisting of employers, teachers, and parents) and (10 YAIDs) observation techniques, which are qualitative data collection techniques, were used in the study.

\section{Semi-structured interviews}

A data collection tool was developed by the researcher. Interview forms containing eight openended questions aimed at determining the independent living needs of YAIDs were prepared for each group of participants. The interview questions were submitted to expert opinion to test the validity. Then, a pilot interview was conducted from each group. Furthermore, according to information expressed by Rubin and Rubin (2005) for the semi-structured interviews conducted in this study and Creswell's (2008) principles of interviewing, an interviewer's guide specific to this study was prepared by the researcher. Thirty interviews were completed in two months (January-February, 2017) and all of them were recorded.

\section{Skill control list}

In addition to the interviews, 10 YAIDs were observed, and the skills and behaviors they could and could not exhibit were marked on the skill control list. The skill control list can be expressed as an assessment and evaluation instrument in the form of a checklist to determine to what extent the observed performance complies with the performance criteria by observing 
whether individuals exhibit certain skills and behaviors (Barkley \& Major, 2016; Creswell, 2014). The skill control list used in this study is a data collection tool developed by the researcher. The skill control list was prepared for YAIDs over the age of 18 who had completed formal education. The list, which was finalized by receiving the opinions of twenty domain experts, has three main skill areas and the relevant skills and behaviors under them. They consist of a total of 573 items, including a) 358 items for daily life skills, b) 156 items for selfdetermination and interpersonal skills, and c) 59 items for employment skills. The skill control list was organized by receiving the opinions of five domain experts. The implementation of the checklist was carried out by an independent expert, and feedback was received regarding the process of using the tool.

The researcher had previously given on-the-job training to the group she would observe. Since the researcher was acquainted with the target group, the sincerity desired before the observation was provided as much as possible. Although this situation allowed individuals to act naturally, the researcher paid attention to taking the necessary measures for it. In the list, observable items were marked by observing young adults for an average of 20 days in the environments where individuals were educated and working, while unobservable items were marked by asking parents/teachers/employers of individuals. Ten YAIDs were observed in their workplaces for a month, and their knowledge and skill needs were evaluated.

For all interviews and observations, the approval forms created by the researcher were used by utilizing the World Health Organization's approval form, and all participants' written permissions and voice-recorded verbal permissions were obtained. And also on 10.10.2016 ethical committee approval numbered 105775 was obtained from Anadolu University Ethics Committee. All stages of the study were followed in accordance with research and publication ethics.

\section{Data Analysis}

The data obtained from semi-structured interviews were analyzed by content analysis, and the data obtained from the skill control list were analyzed by descriptive analysis. The content analysis of the interview data was performed using NVivo 11 software. The shortest interview 
lasted $10.07 \mathrm{~min}$, the longest one lasted $41.02 \mathrm{~min}$. The average duration of all interviews is $18.92 \mathrm{~min}$.

\section{Validity-Reliability}

For validity and reliability in qualitative research, credibility, transferability, consistency and conformability studies were conducted (Guba \& Lincoln, 1989; Merriam, 2013).

\section{Credibility}

In this study for credibility, (a) peer debriefing, expert opinion was received in the stages of developing data collection tools, transcription and analysis of data, and the presentation of findings, (b) persistent observation, the researcher conducted in-depth interviews and observations with a total of 30 people from four different data sources (young adults, parents, employers, and teachers) to ensure the adequacy of the data they collected, and the results were compared and the patterns were revealed, (c) member checks, in the interview process after creating the themes, a parent, a teacher, and an employer providing the richest data from each group were interviewed again, and feedback on the findings obtained was required, (d) data collection from four different data sources, including employers, teachers, parents, and YAIDs, using two different data collection techniques, including observation and interviewing, served triangulation, and (e) prolonged engagement, the researcher had long-term interactions by spending about two months in order to make observations about the research problem in the environments where YAIDs worked and received education.

\section{Transferability}

Appropriate and adequate participation strategies were used with (a) rich and thick description and (b) purposeful sampling to demonstrate transferability. Rich and thick description; all processes, from the development of data collection tools to data collection techniques, from data analysis to the presentation of results, were described in detail in the study. Various and adequate participation with purposeful sampling; 40 individuals selected by purposeful sampling participated in the study. YAIDs, each of which consisted of groups of 10 individuals, and their parents, employers, and teachers served both quantitative and qualitative transferability by enabling the diversification of the sample. 


\section{Consistency}

For consistency feedback was received by the members of the thesis committee (three Ph.D. experts) and an independent domain expert with $\mathrm{Ph} . \mathrm{D}$. in order to examine whether the researcher conducted this research in the same approach (conducting a consistent study) in the process of data collection, data analysis, and presentation of findings.

\section{Conformability}

For conformability study, the "intercoder agreement" study was conducted in the data analysis process by another independent expert. Afterward, the researcher and the independent expert came together to check the matching of the codes and non-matching codes were discussed, and an agreement was reached. Miles, Huberman, and Saldana (2014) calculated the consistency coefficient between coders before the agreement with the formula "(agreement/agreement+disagreement)x 100" and stated that there should be at least $70 \%$ consistency. The findings on intercoder reliability the agreement was $83 \%$ before the agreement and increased to $100 \%$ after the independent coder and researcher agreed. In the reliability study for the data obtained from the Skill Control List, the data obtained were analyzed by descriptive analysis by both the researcher and independent expert, and the frequencies of the resulting items were compared.

\section{Findings}

Interviews were based on confidentiality, and the code names consisting of the initials and sequential numbers of each group were used instead of the real names of the participants. Accordingly, employers were named as E1, E2, E3,..., E10, teachers were named as T1, T2, $\mathrm{T} 3, \ldots, \mathrm{T} 10$, and parents were named as $\mathrm{P} 1, \mathrm{P} 2, \mathrm{P} 3, \ldots, \mathrm{P} 10$.

Six important themes selected from the themes obtained from the interviews were decisive in determining the needs of YAIDs. These themes are presented in Table 1. The sub-themes within the themes were listed by frequency, and only high-frequency sub-themes were quoted in the presentation of findings. 
Table 1

Themes from Interviews

\begin{aligned} & \hline \multicolumn{2}{l}{ Themes } \\ & \hline 1. Difficulties of YAIDs in Preparing for Adulthood and Work Life \\ & 2. Causes of Difficulties of YAIDs in Preparing for Adulthood and Work Life \\ & 3. After-School Independent Life Experiences of YAIDs \\ & 4. Reasons for the Need for an Independent Life Education Program \\ & 5. Topics Needed in the Independent Life Education Program \\ & 6. The Priority of the Topics Needed in the Independent Life Education Program \\ & \hline\end{aligned}

\section{Difficulties of YAIDs in Preparing for Adulthood and Work Life}

In Figure 1, it appears that the difficulties of YAIDs were collected under three main headings, including difficulties in daily life, self-determination and interpersonal skills, and preparation to employment, and divided into various sub-themes.

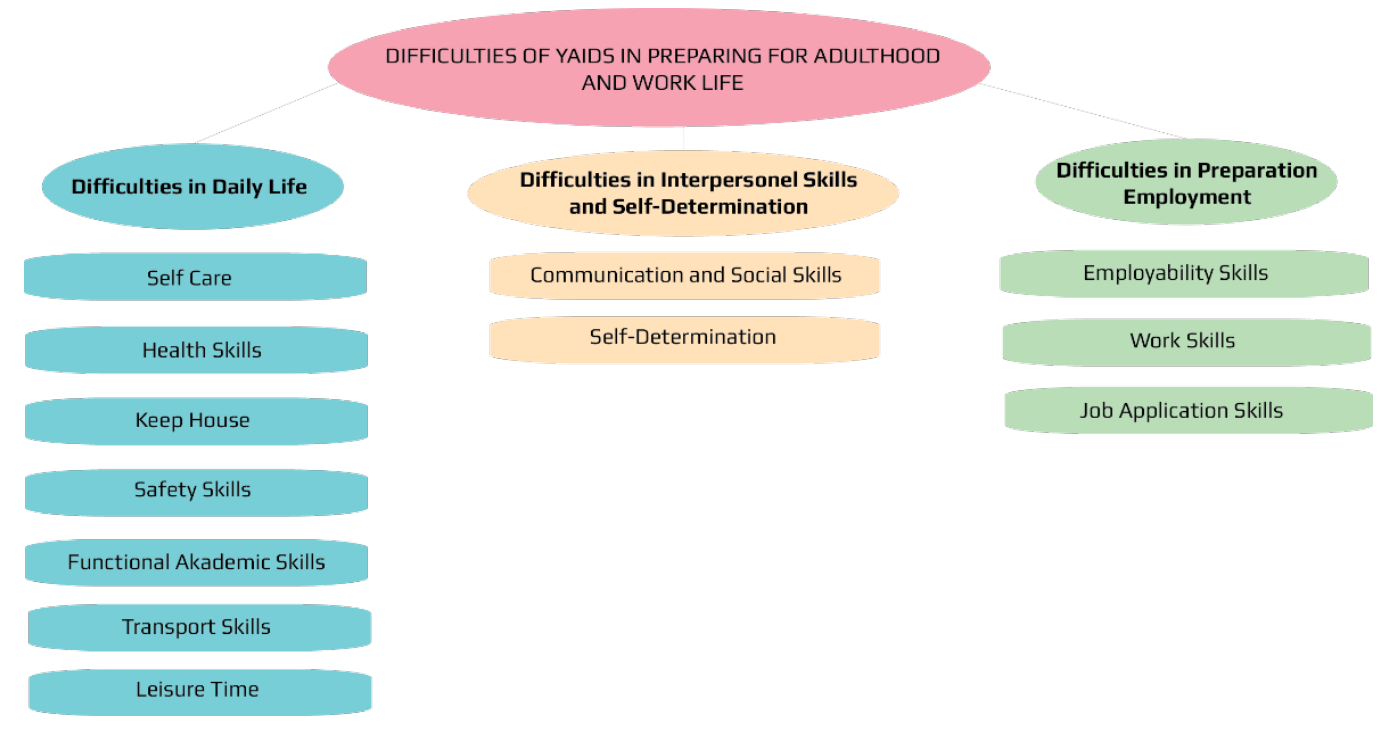

Figure 1. Difficulties of YAIDs in preparing for adulthood and work life

With respect to the difficulties in self-care in the field of daily life, T3 stated that "...I think the biggest difficulty is in self-care, I mean, it is the most necessary issue for the child to exist independently in life...". About difficulties in health skills, E6 stated that “...we realize that he cannot understand himself about sexual life ...".

The difficulties in self-determination and interpersonal relations emerged in communication and social skills. The majority of the participants stated that YAIDs could not express 
themselves. The views of the participants were "...employers mainly prefer people who can express themselves well ...” (T10) and “...the primary reason why these students cannot get into a job is the weakness of communication skills ..." (T4).

YAIDs had difficulties in employability skills, work skills, and the job application process in preparation for employment. About on employability skills, E2 stated that "...they don't know how to talk to the boss... especially interaction with customers can be very troublesome..." and indicated that these individuals had difficulty in establishing a relationship in accordance with the hierarchy. T5 indicated that they could not comply with the working discipline by stating that "...it is necessary to ensure that these children gain working discipline...".

According to these findings, it appeared that they had difficulties mostly in daily life skills. It is remarkable that the most challenging issues in daily life were concentrated in self-care, health, and safety skills. Also there were difficulties in self-determination and interpersonal relationships, employability skills.

\section{Causes of Difficulties of YAIDs in Preparing for Adulthood and Work Life}

As is seen in Figure 2, the reasons why YAIDs had difficulties in adulthood and work life were gathered under six themes. Almost all participants $(\mathrm{f}=24)$ indicated that the lack of knowledge and skills played a significant role in the difficulties of YAIDs in adulthood and work life. With respect to the opinions on it, P6 stated that “...they need to be guided problems are caused by the lack of knowledge ...". 


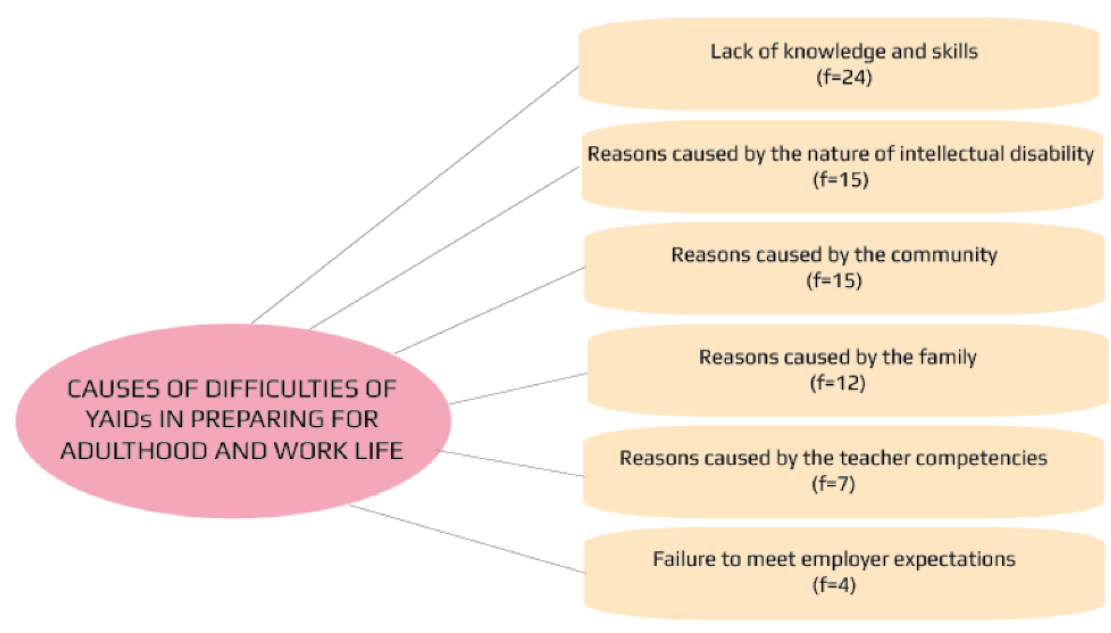

Figure 2. Causes of difficulties of YAIDs in preparing for adulthood and work life

\section{After-School Independent Life Experiences of YAIDs}

According to the findings, almost all of the YAIDs did not attend any post-secondary education after completing formal education. According to Figure 3, it appeared that there were very few participants indicating that they had education on after-school independent life experiences. Participants stated that the post-secondary education was vocational education in which only work skills were taught, rather than comprehensive independent life education.

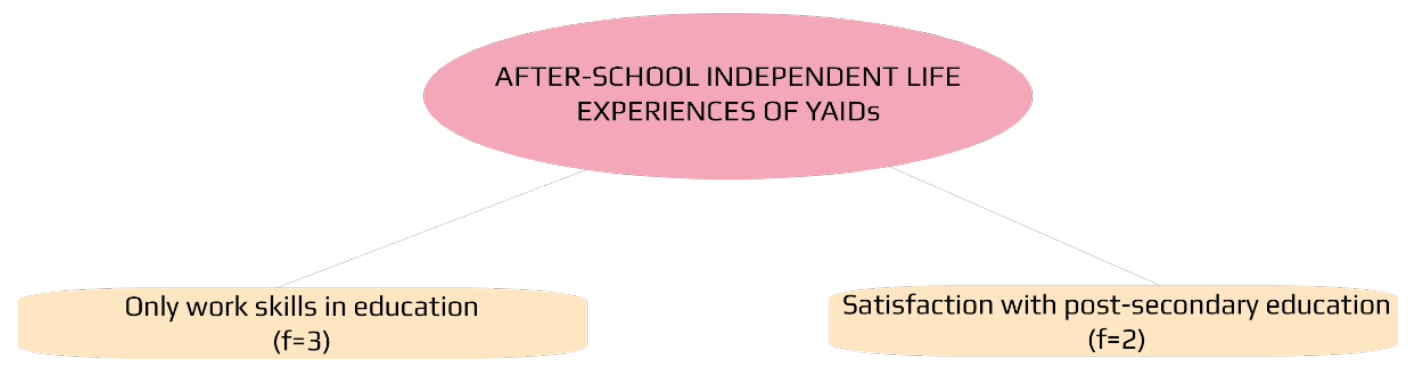

Figure 3. After-school independent life experiences of YAIDs 


\section{Reasons for the Need for an Independent Life Education Program}

All of the participants interviewed $(\mathrm{f}=30)$ stated that there was a need for an education program to design independent living skills for YAIDS in preparing for adulthood and work life. As is seen in Figure 4, the participants stated that the reasons why they needed such education were that individuals had difficulties in organizing their own lives and living independently and that there was a need for qualified education requiring expert knowledge.

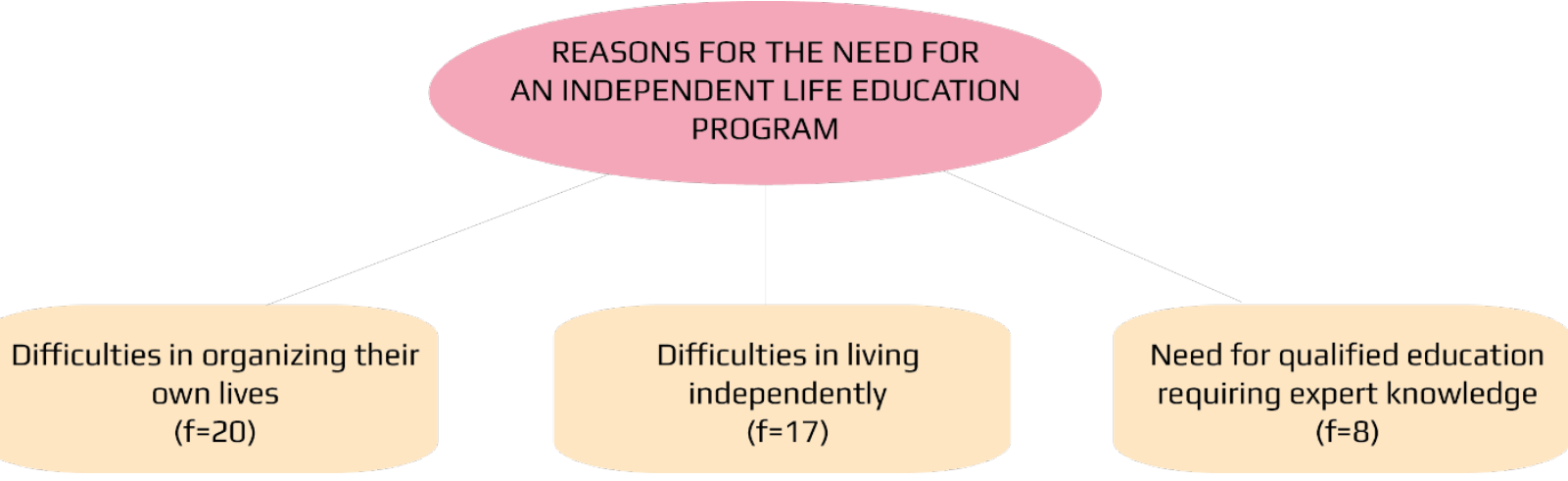

Figure 4. Reasons for the need for an independent life education program

With respect to difficulties in independent living, P8 stated that “...such education should be provided so that he would be self-sufficient and can continue his life without needing anybody ...". Regarding the fact that the education to be provided should be qualified and requires expert knowledge, E6 expressed his opinions by stating that “...his employer and his workmates do not have to take care of him, they do not have to educate him, when we look at it, it should be done professionally, that education should be provided professionally ...".

\section{Topics Needed in the Independent Life Education Program}

The topics that should be included in the independent life education program to be provided for YAIDs' preparation for adulthood and work life were collected under three main headings, including the topic in *daily life, *self-determination and in interpersonal relations, and *preparation to employment. As is seen in Figure 5, the topics that were most needed in daily life were expressed as self-care (fsum=26) and health (sexuality) skills (fsum=22). It was indicated that education was needed on self-determination (fsum=52) and communication and 
social skills (fsum=38) in interpersonal relations. Employability skills (fsum=29) were the most frequently mentioned topic in the process of preparation for employment.

With respect to self-care in daily life, E5 stated that “...the care of staff is very important in a place where people work intensively ...". Sexuality came to the forefront with regard to health skills, and in this regard, T1 stated that "...there is an approach to the opposite sex, the adult individual will approach the opposite sex but does not know how, how much he should protect his personal boundary ...".

In the self-determination theme, T3 stated that "... we have problem in ensuring the person's self-control..." in the sub-theme of thinking the things to do spontaneously. With respect to interpersonal relations related to communication and social skills, E5 stated that "...communication with other individuals should be the most important issue in education program...". With respect to self-expression, E9 stated that “... at first, these youngs should be taught on how to express themselves...".

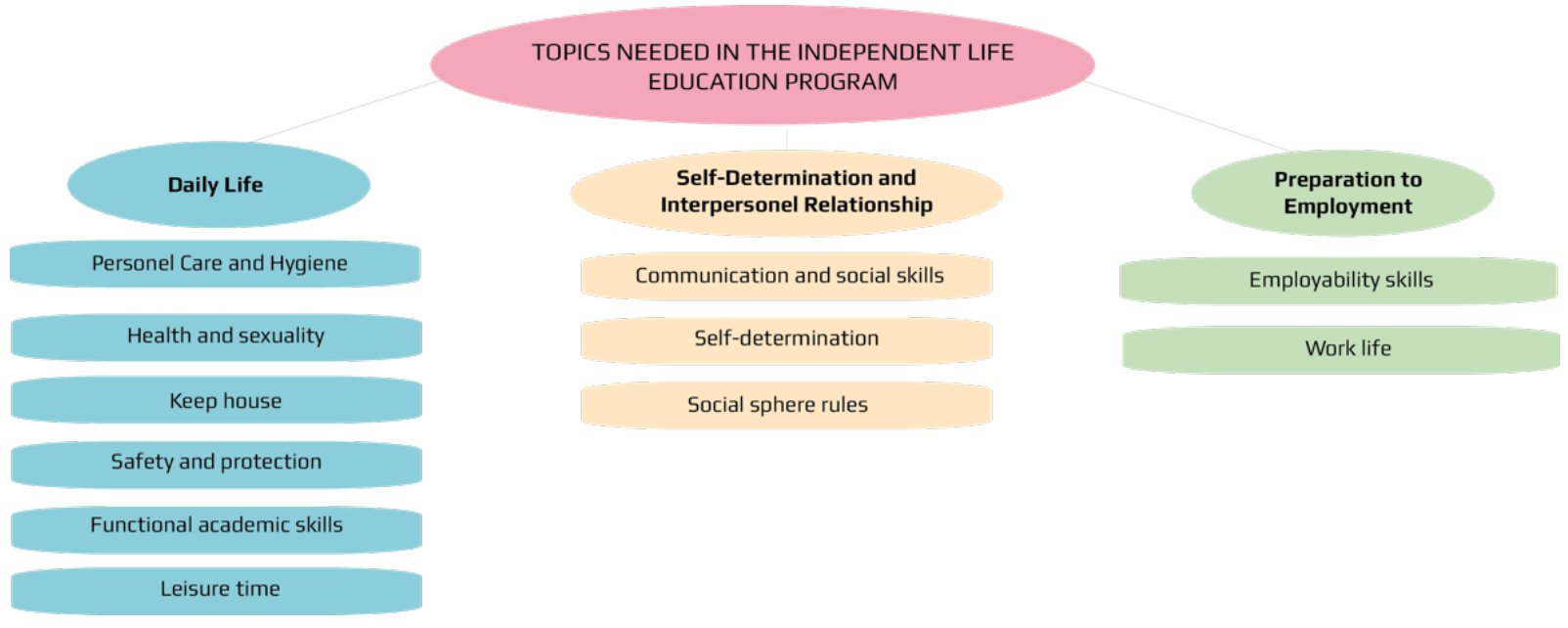

Figure 5. Topics needed in the independent life education program

In preparation for employment, all of the participants emphasized employability skills. With respect to following work discipline and workplace rules under the heading of employability, E10 stated that “... when we look at an individual, we first look at whether he is able to follow the rules of the company's procedures and really has reached the level to receive this information ...". With respect to the opinions on establishing a relationship in accordance with 
the hierarchy, T5 stated that "...it is very important for an individual to know the person to whom he is responsible and to know that he is a superior ...".

\section{The priority of the Topics Needed in the Independent Life Education Program}

When the participants were asked to prioritize the topics they needed, while protection from abuse, security, and personal care and hygiene were of first priority regarding daily life, it was indicated that the establishment of interpersonal relations was the highest priority in interpersonal skills. Among the topics of top priority, no opinion on employment skills was expressed.

\section{Findings from the Skill Control List}

At first, the most frequently stated items in the skill control list were determined. Afterward, among these items, the items compatible with the interview findings were included in the needs of YAIDs. The criteria for determining the most frequently expressed item was being marked for at least seven of the 10 YAIDs observed. Accordingly, findings from the skill control list, most frequently expressed items are *prevention of neglect and abuse, *healthy sexual development, *interpersonal skills, *safety skills in community settings, *self-determination, *prevocational skills, *care of clothes, *self-expression, *employability skills, *personal care and hygiene, *time management, *community use.

It appeared that the findings obtained from the interviews (Figures 5) and the skill control list were largely compatible. When the interview and observation findings were examined together, the needs of YAIDs in preparing for adulthood and work life could be listed as personal care and hygiene, interpersonal skills, self-determination, health and sexual education, security, using community resources, and preparing for work life. Functional academic skills are embedded in these topics. 


\section{Discussion and Conclusion}

YAIDs' independent livings needs and post-secondary needs refer especially employment and work life. This study examined the needs of YAIDs in in preparing for adulthood and work life by semi-structured interviews with parents, teachers, employers and by observations with YAIDs. Results indicated that YAIDs could not use independent living skills in organizing their own lives, that they did not live independently without any support. Providing some information about independent living at home or at work was not sufficient and required expert knowledge. Based on the difficulties of YAIDs, it was concluded that these individuals needed post-secondary independent life education and that personal care and hygiene, selfdetermination and interpersonal skills, employability skills and sexual education and safety skills should be primarily included in the content of this education.

In this study, it was revealed that YAIDs had difficulties in independent living skills in adulthood and work life (Figure 1), the main reason for these difficulties was the lack of knowledge and skills (Figure 2), they needed independent life education in this process (Figure 4), and this education should be provided by an expert within a comprehensive and systematic program (Figure 4). Similarly, in the studies, it was revealed that YAIDs had difficulties in exhibiting independent living skills after school (Luthra et al., 2018), that post-secondary education aimed at improving independent living skills of YAIDs was inadequate due to the lack of effective programs (Alwell \& Cobb, 2009; Bouck, 2010), and that the existing programs should be provided by special education experts (Bouck, 2010; Kaya, 2017; Ruteere et al., 2015).

The findings indicated that the topics in which YAIDs had difficulty (Figure 1) were compatible with the topics needed in the independent life education program (Figure 5). Also, the findings obtained by the observation of YAIDs and the findings obtained from parents, teachers, and employers indicated that the topics in which YAIDs had difficulties were similar. Accordingly, it can be said that the findings obtained from the interviews and observations supported each other.

In this study, the most difficult topics among independent living skills of YAIDs were daily life skills, self-determination, and interpersonal skills and employability skills. In the other 
studies, it was also revealed that YAIDs frequently had difficulties in daily life, interpersonal skills, and employability skills (Alwell \& Cobb, 2009; Baran \& Cavkaytar, 2007; Cosgun Basar, 2010; McLaughlin, 1995; Mueller \& Stack-Dunne, 1989; Sunder, 2007; Thoma et al., 2016; Yuan $\mathrm{Ru}, 2015)$. The biggest reason for difficulties in the relevant skills was found to be YAIDs' lack of knowledge and skills related to independent living. The studies in the literature also indicated the lack of knowledge and skills while explaining the reasons for difficulties in the participation of these individuals in work life (Agran et al., 2016; CEC, 2011; Folk et al., 2012; Luthra et al., 2018; Ozbek et al., 2017; McLaughlin, 1995; Yuan Ru, 2015). Therefore, is is thought that YAIDs need pre-employment independent life education.

In the relevant studies, it was emphasized that the priority needs of YAIDs were personal care, self-care, and health, communication skills, adaptation, appropriate interaction skills, employability skills, use of community resources, just like the results in this study (Agran et al., 2016; Belva \& Matson, 2012; Chou et al., 2013; Folk et al., 2012; Harries et al., 2005; Hilgenkamp et al., 2011; Kaya, 2017; Lamoureux-Hebert et al., 2010; Lane, 2012; Mansell et al., 2002; Mueller \& Stack-Dunne, 1989; Sunder, 2007; Thompson et al., 2009; Wehmeyer et al., 2009; Yuan Ru, 2015). In another group of studies, independent living needs of YAIDs appeared in self-determination, self-command, time management, decision making, making choice, stress management, and behavior management (Harries et al., 2005; Lamoureux-Hebert et al., 2010; Lane, 2012; Sunder, 2007; Thompson et al., 2009; Wehmeyer et al., 2009). Furthermore, studies revealed that these individuals needed support in the self-defense and avoidance of abuse (Gil-Llario et al., 2018; Gimenez-Garcia et al., 2017; Hickson et al., 2008; Sunder, 2007), and sexual education (Brown \& McCann, 2018; Healy et al., 2009; Lumley et al., 1998; Tice \& Harnek, 2008). Consequently, it can be said that results of the relevant studies quite similar to results of this study.

The need for sexual education that emerged in those studies can be explained by the fact that women are more vulnerable to abuse than men and that those with disabilities are more vulnerable to abuse than those without disability (Brown \& McCann, 2018; Gil-Llario et al., 2018; Gimenez-Garcia et al., 2017; Hickson et al., 2008; Hsieh et al., 2012; Nye-Lengerman et al., 2017; Tice \& Harnek, 2008). According to these results, it can be said that safety and sexual education are important for work life. 
As can be seen, the results of other studies that determined the independent living needs of YAIDs are compatible with the needs determined in this study. It can be said that the topics needed in independent life were concentrated in the main headings of daily life skills, personalsocial skills, and employability skills. This result reveals the importance of employability skills rather than vocational skills in preparing for working life. Working life requires gaining independent life skills related to the occupation. Accordingly, it is recommended to organize independent life education for adults before employment. While preparing the independent life education to be provided to these individuals, it is of great importance to determine the needs of the target group and to develop education programs based on these needs (Eisenman et al., 2014; Onukwube, 2010). In this respect, it is considered that the present study will shed light on the planning of independent life education of YAIDs.

Post-secondary education in Turkey is planned in the form of short-term courses or trainings in projects focusing on occupational skills. I can be said that post-secondary education in Turkey is insufficient for sustainable employment. To support the sustainable employment of YAIDs, comprehensive independent life education that work on employability skills should be organized.

The main conclusion of the study was that it was needed that YAIDs should be provided with the acquisition of knowledge and skills related to adulthood and work life. In future research, education programs that take into account the needs determined in this study should be designed, and the effect of the programs should be examined. Similarly, a similar study can be planned to determine the needs of young adults with autism. In this study, the target group was YAIDs, and qualitative studies can be planned to examine the needs of elderly people with intellectual disabilities. In future research, it is recommended that studies should be carried out to determine the needs before organizing education for IIDs.

\section{Statements on ethics and conflict of interest}

On 10.10.2016 ethical committee approval numbered 105775 was obtained from Anadolu University Ethics Committee. All stages of the study were followed in accordance with research and publication ethics. 


\section{References}

Agran, M., Hughes, C., Thoma, C. A., \& Scott, L. A. (2016). Employment social skills: What skills are really valued?. Career Development and Transition for Exceptional Individuals, 39(2), 111-120.

Aile, Calisma ve Sosyal Hizmetler Bakanligi Turkiye Is Kurumu. (2018). Isgucu Piyasasi Arastirmasi Turkiye Raporu (IPA). Ankara.

Alwell, M., \& Cobb, B. (2009). Functional life skills curricular interventions for youth with disabilities: A systematic review. Career Development for Exceptional Individuals, $32(2), 82-93$.

Arnett, J. J. (2007). Emerging adulthood: What is it, and what is it good for?. Child Development Perspectives, 1(2), 68-73.

Baran, N. \& Cavkaytar, A. (2007). Isverenlerin zihinsel yetersizligi olan bireylerin istihdamlarina iliskin gorus ve onerileri. Ilkogretim Online Dergisi, 6(2), 213-225.

Barkley, E. F., \& Major, C. H. (2016). Learning assessment techniques: A handbookfor college faculty. San Francisco: Jossey-Bass.

Belva, B. C., \& Matson, J. L. (2013). An examination of specific daily living skills deficits in adults with profound intellectual disabilities. Research in Developmental Disabilities, 34(1), 596-604.

Bouck, E. C. (2010). Reports of life skills training for students with intellectual disabilities in and out of school. Journal of Intellectual Disability Research, 54(12), 1093-1103.

Brolin, D. E. (1997). Life centered career education: A competency based approach. (5th Edition). USA: The Council for Exceptional Children.

Brown, M., \& McCann, E. (2018). Sexuality issues and the voices of adults with intellectual disabilities: A systematic review of the literature. Research in Developmental Disabilities, 74, 124-138. 
Chou, Y. C., Lee, Y. C., Chang, S. C., \& Pei-Lung Yu, A. (2013). Evaluating the supports intensity scale as a potential assessment instrument for resource allocation for persons with intellectual disability. Research in Developmental Disabilities, 34, 2056- 2063.

Cosgun Basar, M. (2010). Ozel gereksinimi olan bireylerin okul hayatindan is hayatina gecis becerilerinin anne-baba goruslerine gore belirlenmesi. Yayimlanmis Yuksek Lisans Tezi. Ankara: Ankara Universitesi, Egitim Bilimleri Enstitusu.

Council for the Education of Exceptional Children (CEC). (2011). Reauthorization of the workforce investment act (WIA): Priorities \& concerns for students with disabilities. Issue Brief. USA: Arlington.

Creswell, J. W. (2008). Educational research planning, conducting, and evaluating quantitative, and qualitative research. (3th Edition). Pearson Education International.

Creswell, J. W. (2014). Research design: qualitative, quantitative, and mixed methods approaches. (4th Edition). SAGE Publications.

Eisenman, D. P., Bazzano, A., Koniak-Griffin, D., Tseng, C. H., Lewis, M. A., Lamb, K., \& Lehrer, D. (2014). Peer-mentored preparedness (PM-Prep): A New disaster preparedness program for adults living independently in the community. Mental Retardation, 52(1), 49-59.

Faloon, B. J., \& Rehfeldt, R. A. (2008). The role of overt and covert self-rules in establishing a daily living skill in adults with mild developmental disabilities. Journal of Applied Behavior Analysis, 41(3), 393-404.

Folk, E. D., Yamamoto, K. K., \& Stodden, R. A. (2012). Implementing inclusion and collaborative teaming in a model program of postsecondary education for young adults with intellectual disabilities. Journal of Policy and Practice in Intellectual Disabilities, 9(4), 257-269.

Gil-Llario, M. D., Morell-Menguel, V., Diaz-Rodriguez, I., \& Ballester-Arnal, R. (2019). Prevalence and sequelae of self-reported and other-reported sexual abuse in adults with intellectual disability. Journal of Intellectual Disability Research, 63(2), 138-148.

Gimenez-Garcia, C., Gil-Llario, M. D., Ruiz-Palomino, E., \& Diaz-Rodriguez, I. (2017). Sexual abuse and intellectual disability: How people with intellectual disabilities and 
their professionals identify and value the experience. International Journal of Developmental and Educational Psychology, 4(1), 129-136.

Guba, E. G., \& Lincoln, Y. S. (1989). Fourth generation evaluation. SAGE Publication.

Gundogdu, A. (2010). Bir ilkogretim okulu ve is okulunda calisan okul yoneticisi ve ogretmenlerin zihin engelli bireylerin ise yerlestirilmelerine iliskin gorusleri. Yayimlanmis Yuksek Lisans Tezi. Eskisehir: Anadolu Universitesi, Egitim Bilimleri Enstitusu.

Gunes, N., \& Akcamete, G. (2014). Ozel gereksinimi olan bireylerin mesleki istihdami Corum ili ornegi. Ankara Universitesi Egitim Bilimleri Fakultesi Ozel Egitim Dergisi, 15(03), 117.

Gursel, O., Ergenekon, Y. ve Batu, S. (2007). Gelisimsel yetersizligi olan bireylere okuldan ise gecis becerilerinin kazandirilmasina iliskin ogretmenlerin ve yoneticilerin gorusleri. Abant İzet Baysal Universitesi Egitim Fakultesi Dergisi, 7(2), 54-77.

Harries, J., Guscia, R., Kirby, N., Nettelbeck, T., \& Taplin, J. (2005). Support needs and adaptive behaviors. American Jorunal on Mental Retardation, 110(5), 393-404.

Harris, J. C. (2006). Intellectual disability: Understanding its development, causes, classification, evaluation, and treatment. London: Oxford University Press.

Hasircioglu, A. (2006). Isverenlerin ozurlu istihdamina yaklasimi. Yayinlanmis Yuksek Lisans Tezi. Sakarya: Sakarya Universitesi, Egitim Bilimleri Enstitusu.

Healy, E., McGuire, B. E., Evans, D. S., \& Carley, S. N. (2009). Sexuality and personel relationships for people with an intellectual disability. Part I: service-user perspectives. Journal of Intellectual Disability Research, 53(2), 905-912.

Hickson, L., Khemka, I., Golden, H., \& Chatzistyli, A. (2008). Profiles of women who have mental retardation with and without a documented history of abuse. American Journal on Intellectual and Developmental Disabilities, 113(2), 133-142.

Hilgenkamp, T. L., Wijck, R., \& Evenhuis, H. M. (2011). Instrumental activities of daily living in older adults with intellectual disability. Research in Developmental Disabilities, 32(5), 1977-1987. 
Hsieh, K., Rimmer, J., \& Heller, T. (2012). Prevalence of falls and risk factors in adult with intellectual disability. American Journal on Intellectual and Developmental Disabilities, $117(6), 442-454$.

Kaya, A. (2017). Bakim ve koruma altinda bulunanzihin yetersizligi olan bireylere yonelik gunluk yasam egitimi programi gelistirilmesi. Yayimlanmis Doktora Tezi. Eskisehir: Anadolu Universitesi, Egitim Bilimleri Enstitusu.

Lamoureux-Hebert, M., Morin, D., \& Crocker, A. (2010). Support needs of individuals with mild and moderate intellectual disabilities and challenging behaviors. Journal of Mental Health Research in Intellectual Disabilities, 3(2), 67-84.

Lane, V. (2012). Examining attachment in person with a disability and their transition to independent living. Published Master's Thesis. USA: Saint Mary's College of California.

Lumley, V. A., Miltenberger, R. G., Long, E. S., Rapp, J. T., \& Roberts, J. A. (1998). Evaluation of a sexual abuse prevention program for adults with mental retardation. Journal of Applied Behavior Analysis, 31(1), 91-101.

Luthra, R., Högdin, S., Westberg, N., \& Tideman, M. (2018). After upper secondary school: Young adults with intellectual disability not involved in employment, education or daily activity in Sweden. Scandinavian Journal of Disability Research, 20(1), 50-61.

Mansell, M. J., Ashman, B. McDonald, S., \& Beadle-Brown, J. (2002). Deinstitutionalisation and community living: Position statement of the comparative policy and practice special interest research proup pf the international association for the scientific study of intellectual disabilities. Journal of Intellectual Disability Research, 46(8), 625-633.

McLaughlin, M. (1995). Employability skills profile: what are employers looking for?. ERIC Clearinghouse on Counseling and Student Services Greensboro NC., Canadian Guidance and Counselling Foundation Ottawa (Ontario).

Merriam, S. B. (2013). Nitel arastirma desen ve uygulama icin bir rehber. (Cev: S. Turan). Ankara: Nobel Akademik Yayincilik.

Ministy of National Education. (2018). Special education services regulations. http://www.resmigazete.gov.tr/eskiler/2018/07/20180707-8.htm (Accessed Date: 23.10.2018). 
Mueller, M. M., \& Stack-Dunner, S. E. (1989). A study to test the reliability of an independent living skills assessment instrument. California: San Jose State University Department of Occupational Thearpy.

Nye-Lengerman, K., Narby, C., \& Pettingell, S. (2017). Bringing Employment First to Scale: What is the relationship between gender end employment status for individuals with IDD?. Boston, MA: University of Massachusetts Boston, Institute for Community Inclusion.

Onukwube, V. C. (2010). Experiences, feelings, and perceptions of former foster care youth about independent living program. Published Doctoral Dissertation. U.S.: Walden University.

Ozbek, A. B., Girli, A., \& Ozturk, H. (2017). Investigating the opinions of teachers on the processes of vocational counselling, training and employment of special needs students. Journal of Education and Training Studies, 5(12), 41-50.

Ozbey, F. (2015). Zihin yetersizligi olan ogrencilere is analizi temelinde tekstil isciligi becerilerinin ogretilmesi: Eylem arastirmasi. Yayimlanmis Doktora Tezi. Ankara: Ankara Universitesi, Egitim Bilimleri Enstitusu.

Rubin, H. J., \& Rubin, I. S. (2005). Qualitative interviewing the art of hearing data (2nd Edition). SAGE Publications.

Ruteere, R. K., Mutia, J. M., Mwoma, T., \& Runo, M. (2015). Challenges experienced in teaching daily living skills to learners with mental retardation. Journal of Education and Practice, 6(18), 159-163.

Sabornie, E. J., \& DeBettencourt, L. U. (2009). Teaching students with mild and high-incidence disabilities at the secondary level. Prentice Hall.

Shalock, R. L., Borthwick-Duffy, S. A., Brandley, V. J., Buntinx, W. H. E., Coulter, D. L., Craig, E. M., Gomez, S. C., Lachapelle, Y., Luckasson, R., \& Reeve, A. (2010). Intellectual disability definition, classification, and systems of supports. AAIDD Publication.

Steere, D. E., Rose, E., \& Cavaiuolo, D. (2007). Growing up: Transition to adult life for students with disabilities. Pearson: Allyn and Bacon. 
Sunder, V. (2007). Development of an instrument for the evaluation of independent living skills in adults with disabilities. Published Doctoral Dissertation. U.S.: State University of New York Depermant of Rehabilitation Science.

Thoma, C. A., Browder, D., Lemons, C., Thurlow, M., Morningstar, M., Agran, M., Goode, T., Carslon, D., Lowery, A., Scott, L. A., Terpstra, J., Johnson, D. R., Thompson, J. \& Cain, I. (2016). Education of students with intellectual and developmental disabilities. P. V. Berns, J. Butterworth, D. Carlson, T. Heller, A. Hewitt, A. Imparato, W. B. Jackson, A. Lulinski, M. Nygren, \& D. Webber (Eds.) in Critical issues in intellectual and developmental disabilities: Contemporary, research, practice and policy, (p. 37-71). AAIDD Publication.

Thompson, J. R., Bradley, V. J., Buntinx, W. H., Schalock, R. L., Shogren, K. A., Snell, M. E., ... \& Gomez, S. C. (2009). Conceptualizing supports and the support needs of people with intellectual disability. Intellectual and Developmental Disabilities, 47(2), 135-146.

Tice, C. J., \& Harnek Hall, D. M. (2008). Sexuality education and adolescents with developmental disabilities: Assessment, policy, and advocacy. Journal of Social Work in Disability \& Rehabilitation, 7(1), 47-62.

Wandry, D., Wehmeyer, M. L., \& Glor-Scheib, S. (2013). Life centered education: The teacher's guide. Council for Exceptional Children.

Wehman, P. (2013). Transition: New horizons and challenges. P. Wehman (Ed.) in Life beyond the classroom: Transition strategies for young people with disabilities, (p. 3-41). Baltimore, MD: Brookes Publishing Company.

Wehmeyer, M. L., Chapman, T. E., Little, T. D., Thompson, J. R., Schalock, R., \& Tasse, M. (2009). Efficacy of the support intensity scale (SIS) to predict extraordinary support needs. American Journal of Intellectual and Developmental Disabilities, 114(1), 3-14.

Yuan $\mathrm{Ru}, \mathrm{H}$. (2015). New home, hearty hope-the experience of community living and independent living program for people with mental disability. Published Doctoral Dissertation. China: Tzu Chi University. 